\title{
Impact of Systemic Risks on Islamic Banks Performance
}

\author{
Bader Mustafa Al-Sharif ${ }^{1}$ \\ ${ }^{1}$ Faculty of Business, Tafila Technical University, At-Tafila, Jordan \\ Correspondence: Bader Mustafa Al-Sharif, Faculty of Business, Tafila Technical University, At-Tafila, Jordan. \\ AT-Tafila, P.O. Box 179, Tafila, 66110, Jordan. E-mail: bader.alsharif99@ gmail.com
}

Received: February 13, 2018

Accepted: April 10, 2018

Online Published: April 20, 2018

doi:10.5539/ijef.v10n5p221

URL: https://doi.org/10.5539/ijef.v10n5p221

\begin{abstract}
The current study aims at identifying impact of systemic risks on Islamic banks performance: evidence from Jordan as measured by return on assets. The financial reports issued by Islamic Bank of Jordan and Islamic International Arab Bank for the periods (2007-2016) were referred to. The analytical and descriptive approach were applied in order to achieve the objectives and the results of the current study. (E-views) software was applied in order to examine the hypotheses of the study and to answer its questions through Simple \&Multiple Linear Regression analysis.

The most significant findings of the study was the presence of statistically significant effect of systemic banking risks (capital risks, liquidity risks, credit risks, operational risks) on the performance of Jordanian Islamic banks.

The current study recommended that Islamic banks should diversify in financing and investment methods to reduce systemic banking risks and to establish specialized risk departments and activate their role to reduce the negative effects of systemic risks on the performance of Islamic banks in order to continue in the market.
\end{abstract}

Keywords: systemic banking risks, performance, Islamic banks

\section{Introduction}

\subsection{Introduce the Problem}

The expansion of financing and investment methods and the provision of various banking services that do not conflict with the Shariah Islamic law are among the objectives pursued by Islamic banks to achieve the highest profits, thus increasing their ability to continue operations in the market. This has led to increased interest in risk due to the fact that the work of Islamic banks should be performed in an environment that is characterized by speed, accuracy and quality, while adhering to Shariah principles what increased its exposure to risk (credit risks, operational risks, capital risks, market risk and liquidity risk), so it is the responsibility of the Islamic Banks Department to manage the funds efficiently and to protect them from loss by reducing the negative effects of systemic risk to as little as possible and then achieving the highest return on assets within the Islamic Shariah principles, hence the objective of the current study is to identify the effect of systemic banking risks on the performance of Jordanian Islamic banks.

\subsection{Study Question}

What is the effect of systemic risk (capital risks, liquidity risks, credit risks, operational risks) on the performance of Jordanian Islamic banks?

\subsection{Objectives of the Study}

The need for Islamic banks in the economy is to achieve the highest return on assets through access to the minimum risk to Islamic banks, and based on this principle, the objectives of the current study can be summarized in the following:

1) The identification of the systemic risks.

2) Studying the effect of systemic risk (capital risks, liquidity risks, credit risks, operational risks) on the performance of Jordanian Islamic banks.

\subsection{Importance of the Problem}

The importance of the current study stems from the importance of maximizing the return on assets and, the 
reduction of the impact of systemic banking risks and the importance of the Islamic banking sector in the economy. Therefore, the importance of the current study is to focus on identifying the effect of systemic risk on the performance of Islamic banks.

\subsection{Literature Review}

Khan describes the concept of risk, its management methods and measurement criteria, and the most predominant risks that characterize the Islamic financial services industry. This study has applied descriptive analytical approach. A questionnaire was distributed to 68 Islamic financial institutions in 28 countries, 17 of which have responded in 10 countries. The study concluded that liberalization of financial markets is accompanied by increased risk, and through risk management, financial institutions can control undesirable risks. (Khan, 2001).

Beltagy identifies the sources of risk in Islamic banks, to generalize a risk measurement model, and to propose a risk tracking plan in Islamic banks. The study sample included all 16 banks inside Saudi Arabia and 5 banks abroad. The researcher has distributed 35 questionnaires. The study has applied the deductive and applied approach to identify criteria and indicators for measuring the risks of Islamic banks. One of the most important findings of the study was that Islamic banks pay attention to the existence of a system and management of risk control, and also pay attention to an accounting model to measure risks; such system fits with the nature and importance of Islamic banks to develop performance (Beltagy, 2005).

Boukri analyzes the risks of Islamic financing formulas in Saudi banks. It also pointed out the need to reduce risks in Islamic banks to increase the efficiency of allocating financing resources, especially after the high liquidity ratio resulting from increasing the number of investors and depositors and opening current accounts to avoid usury in traditional banks. The study has applied the deductive approach based on the study of the theoretical principles governing Islamic banking finance in order to develop the hypotheses and the degree of risks associated with them. The study found several results, the most important of which were that Islamic banks rely on Murabaha and Tawarruq systems at the expense of other systems that are closer to the characteristics of Islamic finance. Also, the results of the study have revealed that Islamic financing risks are higher than financing risks in traditional banks (Boukri, 2005).

Hammad identifies the concept of investment risks in Islamic banks, in addition to their nature and sources, and the impact of high risk of investment in these banks. Inductive approach and comparison between traditional banks and Islamic banks were followed. The study sample included ten Islamic banks. The study has revealed several results, the most important of which were that the investments of Islamic banks face a higher risk than traditional banks. Also, Islamic banks also face many risks because they do not carry out feasibility studies for investment projects. (Hammad, 2008).

Shehzad assesses the financial performance of Islamic and traditional banks in Pakistan using profitability ratios, liquidity ratios, risk and efficiency. Financial ratios such as return on assets (ROA), return on equity (ROE), loan to deposit ratio (LDR), Loan-to-asset ratio (LAR), debt to equity ratio (DER), asset utilization (AU) and income-to-expenditure ratio (IER) are used to assess the Bank. The study found several results; the most important of which were that the profitability of the Islamic bank is lower than the traditional one, but Islamic banks are less risky than traditional banks. The Islamic bank is also less efficient compared to the average of the five traditional banks. However, there was no significant difference in liquidity between the two banking groups. (Shehzad, 2008).

Tahrawi \& Ben Habib, This study aimed at revealing the reality of Islamic banking under Basel Standards, and identifying the extent to which Islamic banks can apply new standards, and testing the performance of risk management at Al Baraka Banking Group and Kuwait Finance House. The study has applied the descriptive approach, the normative approach and the comparative approach. The study sample included Al Baraka Group and Kuwait Finance House for the period 2004-2010. The study concluded that the required safety margin was achieved in both groups, which was a good indicator of risk management. Both groups were exposed to the same risks: liquidity risk, credit risk, concentration risk and market risk. (Tahrawi \& Ben Habib, 2013).

Akashi identifies the impact of operational risk on the profitability of Islamic banks operating in Jordan during the period (2008-2014). The study sample included Islamic Bank of Jordan and Islamic International Arab Bank, where data were collected from the semi-annual financial reports issued by the banks sample of the study. In order to achieve the objectives and to reveal the results, the study has applied the analytical and descriptive approach. The study found that there was a significant positive effect on operational risk on return on assets, return on equity, and earnings per share in Islamic banks operating in Jordan (Akashi, 2015). 


\subsection{Distinguishes the Current Study from Previous Studies}

The current study was characterized as the first study as far as the researcher knows that addresses the effect of systemic risks on the performance of Islamic banks in Jordan from practical and applied aspects, where the previous studies were descriptive only.

\section{Theoretical Framework}

\subsection{Defining Banking Risk}

Banking Risk is "the probability of loss, either directly through loss of business results, loss in capital, or indirectly through constraints that limit the ability of the Bank to continue to deliver its services and activities on one hand, and limit its ability to grab opportunities in Banking environment" (FSR, 1999).

"The Institute of Internal Auditor (IIA) USA" defines it as "a concept used to measure uncertainties in operations that affect an organization's ability to achieve its objectives. The effect can be positive or negative. If it is negative, so it is known as risk or threat, although positive, so they are called opportunities" (IIA, 2014).

Based on the above definitions, the bank's management must take all measures to deal with risks and mitigate their negative effects on the performance of Islamic banks.

\subsection{Types of Banking Risks}

Risks in terms of impact on sectors are divided into two types:

First: Systematic Risks: All the risks that affect all loans regardless of the borrower's circumstances due to economic, political and social factors that are difficult to be controlled. Examples of these risks include credit risk, liquidity risk, operational risk, and capital risk, and the study title was quoted from this definition (Abdul Karim, 2007).

1) Credit Risks: The risk arising from the inability of the debtor to meet the financial obligations towards the bank in due time (Issa \& Zurqan, 2010). They can be measured by the following equation (Rayhan, 2002):

$$
\text { Credit Risks }=\frac{\text { Doubtful Debts }}{\text { Total sales and financing }}
$$

2) Liquidity Risks: the risks arising from the Bank's inability to pay the financial liabilities due to lack of liquidity for the short-term operating requirements (Koch \& Scott, 2006; Khan, 2003), and are calculated using the following equation (Abdulhameed, 2000; Alwefaq, 2003):

$$
\text { Liquidity Risks }=\frac{\text { cash assets }(\text { cash }+ \text { bank accounts })}{\text { Total assets }}
$$

3) Operational risks: Risks arising from poor internal controls over operations for insufficient human resources. This definition includes legal risks such as financial fraud and counterfeiting (Hammad, 1999), and is calculated by the following equation (Hammad, 2003):

$$
\text { Operational risks }=\frac{\text { Total employee expenses }}{\text { Number of employees }}
$$

4) Capital Risks: They are the risks arising from insufficient equity to protect the interests of the Bank's customers. Capital risk reflects the extent to which the value of depositors (assets) can be reduced before the impairment of equity is accounted for (Ramadan \& juda, 1996), and calculated by the following equation (Shammary, 2014):

$$
\text { Capital Risks }=\frac{\text { Equity }}{\text { Total assets }}
$$

Second: Non-Systematic Risks: These are the internal risks of a particular company or industry under certain circumstances. Examples of these conditions are poor banking management, administrative errors, labor strikes, and changing tastes of customers as a result of the emergence of new products. The type of exceptional and non-market risks will affect the customer's ability and willingness to pay his obligations towards the grantor bank in the agreed term, which can be avoided by selecting competent and experienced management, qualifying staff and improving control systems (Matar \& Tim, 2005; Abdulkareem, 2007).

\subsection{Return on Assets (ROA)}

It measures the strength of the Bank's assets to generate profits. It is an indicator of the management's efficiency in operating the assets for profit. The higher this ratio is, the more efficient the Bank's performance is to generate profits from its assets and hence to optimize the use of bank's assets (Mohammad, 2013; Haddad, 2012). The return on assets is calculated as follows (Matar, 2003): 


$$
\text { Return on Assets }(R O A)=\frac{\text { Net profit after tax }}{\text { Total assets }} \times 100 \%
$$

\subsection{Bank Size}

It is the total assets, and forms one of the two sides of the entire budget (Abu Al-Hija, 2004; Hamdan \& Iqda, 2013):

$$
\text { Bank size }=\text { total assets }
$$

\section{Methodology}

The study will be based on the analytical descriptive approach to identify the theoretical aspects of the subject of the study. It will be based on the theoretical aspect and the literature review. The study will be used to achieve the objectives and reveal the results based on the hypothesis test and analysis of the indicators and ratios that affect the return on assets in Islamic banks.

Based on this context, the following hypotheses are proposed:

Ho1: There is no statistically significant impact at the level of significance $(\alpha \leq 0.05)$ for systemic banking risks (Capital Risks \& Liquidity Risks \& Credit Risks \& Operational risks) on the performance of Jordanian Islamic banks.

Base on this hypothesis, the following sub-hypotheses emerge:

Ho1-1: There is no statistically significant impact at the level of significance $(\alpha \leq 0.05)$ for systemic banking risks (Capital Risks) on the performance of Jordanian Islamic banks.

Ho1-2 There is no statistically significant impact at the level of significance $(\alpha \leq 0.05)$ for systemic banking risks (Liquidity Risks) on the performance of Jordanian Islamic banks.

Ho1-3: There is no statistically significant impact at the level of significance $(\alpha \leq 0.05)$ for systemic banking risks (Credit Risks) on the performance of Jordanian Islamic banks

Ho1-4: There is no statistically significant impact at the level of significance $(\alpha \leq 0.05)$ for systemic banking risks (Operational risks) on the performance of Jordanian Islamic banks

Ho2: There is no statistically significant impact at the level of significance $(\alpha \leq 0.05)$ for systemic banking risks (Capital Risks \& Liquidity Risks \& Credit Risks \& Operational risks) on the performance of Jordanian Islamic banks due to the size of the bank.

\subsection{Multi Collinearity Test}

The inflation variance coefficient was calculated for each variable according to the hypothesis being tested. The results were as follows:

Table 1. Multicollinearity test results between independent variables

\begin{tabular}{cc}
\hline Variable & VIP \\
\hline Capital Risks & 1.567 \\
Liquidity Risks & 1.243 \\
Credit Risks & 1.257 \\
Operational risks & 1.985 \\
\hline
\end{tabular}

Source: Author.

Table 1 shows that the values of the Variance Inflation Factor were all greater than 1 and less than 10, indicating that there is no problem of Multiple collinearity between the variables of the study (Guajarati, 2004).

To confirm the previous finding, Pearson correlation coefficients were used between the dimensions of the independent variable to ensure that there was no linear correlation between independent variables.

Table 2. The matrix of correlation for the independent variables

\begin{tabular}{lcccc}
\hline Variable & Capital Risks & Liquidity Risks & Credit Risks & Operational risks \\
\hline Capital Risks & 1 & & & \\
Liquidity Risks & $0.201^{* *}$ & 1 & & \\
Credit Risks & $0.246^{* *}$ & $0.221^{*}$ & 1 & \\
Operational risks & $0.645^{* *}$ & $0.312^{*}$ & $0.115^{* *}$ & 1 \\
\hline
\end{tabular}

$(* *)$ statistically significant at $(\alpha \leq 0.01)(*)$ statistically significant at $(\alpha \leq 0.05)$.

Source: Author. 
Table 2 shows that the highest correlation between the independent variables is $(0.645)$. This indicates that there is no multicollinearity between them, as it is less than 0.80 , and therefore, the sample is free of the problem of multicollinearity.

\subsection{Autocorrelation}

Autocorrelation is defined as the relationship between successive random errors calculated from the regression model estimated in the least squares method and the existence of some standard problems. The test is performed using the Durbin-Watson test, which is denoted as (D-W) and compared with two values extracted from the table of this test at the level of significance $(\alpha)$, the number of observations (n) and the number of variables $(k)$, and these two values are denoted as $\mathrm{dl}$ (minimum value) and du (maximum value). If the (D-W) value is greater than $\mathrm{du}$, this indicates that there is no Autocorrelation, and if $(\mathrm{D}-\mathrm{W})$ value was less than $\mathrm{dl}$ this indicates the existence of Autocorrelation (Guajarati, 2004), and Table 3 shows the results of this test for all hypotheses of the study.

Table 3. Test of autocorrelation

\begin{tabular}{ccccc}
\hline Hypothesis & D-W & DI & DU & Conclusion \\
\hline H01-1 & 1.475 & 1.201 & 1.411 & No Autocorrelation \\
H01-2 & 1.430 & 1.201 & 1.411 & No Autocorrelation \\
H01-3 & 1.421 & 1.201 & 1.411 & No Autocorrelation \\
H01-4 & 1.465 & 1.201 & 1.411 & No Autocorrelation \\
H01 & 1.921 & 0.894 & 1.828 & No Autocorrelation \\
H02 & 1.835 & 0.894 & 1.828 & No Autocorrelation \\
\hline
\end{tabular}

Source: Author.

Note that the D-W values for the variables in all of the hypotheses are larger than du, indicating that data are free of Autocorrelation problem, and thus, there is no correlation between random error limits in the regression model.

\subsection{Testing Study's Hypotheses}

Hypotheses of the study were tested by simple \& multiple linear regression analysis, and the results were as follows:

1) The first main hypothesis H01:

There is no statistically significant impact at the level of significance $(\alpha \leq 0.05)$ for systemic banking risks (Capital Risks \& Liquidity Risks \& Credit Risks \& Operational risks) on the performance of Jordanian Islamic banks.

In order to examine the first main hypothesis, multiple regression analysis was used, and the results were as follows:

Table 4. The results of examining the effect of systemic banking risks (Capital Risks \& Liquidity Risks \& Credit Risks \& Operational risks) on the performance of Jordanian Islamic banks

\begin{tabular}{|c|c|c|c|c|c|c|c|c|c|}
\hline \multirow{2}{*}{$\begin{array}{l}\text { Dependent } \\
\text { variable }\end{array}$} & \multirow{2}{*}{$\begin{array}{c}\mathrm{R} \\
\text { correlation } \\
\text { coefficient }\end{array}$} & \multirow{2}{*}{$\begin{array}{c}\mathrm{R}^{2} \\
\text { coefficient of } \\
\text { determination }\end{array}$} & \multirow[b]{2}{*}{$\begin{array}{c}\text { calculated } \\
\text { F }\end{array}$} & \multirow[b]{2}{*}{ Sig $F^{*}$} & \multicolumn{5}{|c|}{ Regression coefficient } \\
\hline & & & & & Statement & $\beta$ & Standard error & calculated T & Sig $t^{*}$ \\
\hline \multirow{5}{*}{$\begin{array}{l}\text { The } \\
\text { performance } \\
\text { of Jordanian } \\
\text { Islamic banks }\end{array}$} & \multirow{5}{*}{0.831} & \multirow{5}{*}{0.691} & \multirow{5}{*}{8.216} & \multirow{5}{*}{0.015} & Capital Risks & -1.903 & 0.874 & -2.776 & 0.023 \\
\hline & & & & & Liquidity Risks & -0.115 & 0.064 & -0.455 & 0.025 \\
\hline & & & & & Credit Risks & 0.226 & 0.009 & 2.131 & 0.010 \\
\hline & & & & & Operational risks & 0.627 & 0.052 & 3.522 & 0.001 \\
\hline & & & & & Regression & -3.808 & 0.988 & -3.627 & 0.005 \\
\hline
\end{tabular}

(*) The effect is statistically significant at $(\alpha \leq 0.05)$.

Source: Author.

The results from Table 4 are that the effect is statistically significant, where calculated $\mathrm{F}$ value is (8.216), and the level of significance ( $\mathrm{Sig} F=0.015)$ which is less than 0.05 , while the correlation coefficient $(\mathrm{R}=0.831)$ refers to the relationship between the variables, in addition to the value of the coefficient of determination was $(\mathrm{R} 2=$ 0.691), pointing out that $(69.1 \%)$ of the variation in (The performance of Jordanian Islamic banks) can be explained by the variation in (Capital Risks \& Liquidity Risks \& Credit Risks \& Operational risks) combined, 
with all other variables constant.

The regression coefficients table showed that the value of $\beta$ when (Capital Risks) has reached (1.903) and the value of $(\mathrm{t})$ is $(2.776)$, and the level of significance $(\mathrm{Sig}=0.023)$, suggesting that the effect was significant for this variable. When the value of $\beta$ (Liquidity Risks) amounted to (-0.115), and that has a value of ( $t)$ is $(-0.455)$, and the level of significance ( $\mathrm{Sig}=0.025)$, suggesting that the effect of this variable is significant. As the value of $\beta$ when (Credit Risks) has reached (0.226) and that has a value of ( $t$ ) is (2.131), and the level of significance ( $\mathrm{Sig}=0.010)$, suggesting that the effect of this variable is significant. As the value of $\beta$ when (Operational risks) has reached $(0.627)$ and that has a value of $(t)$ is $(3.522)$, and the level of significance ( $\mathrm{Sig}=0.001$ ), suggesting that the effect of this variable is significant.

The fourth sub-hypotheses emerging from this hypothesis were subject to simple regression analysis, and the results were as follows:

H01-1: There is no statistically significant impact at the level of significance $(\alpha \leq 0.05)$ for systemic banking risks (Capital Risks) on the performance of Jordanian Islamic banks.

Table 5. The result of examining the effect of systemic banking risks (Capital Risks) on the performance of Jordanian Islamic banks

\begin{tabular}{|c|c|c|c|c|c|c|c|c|c|}
\hline \multirow[b]{2}{*}{ Dependent variable } & \multirow{2}{*}{$\begin{array}{c}\mathrm{R} \\
\text { correlation } \\
\text { coefficient }\end{array}$} & \multirow{2}{*}{$\begin{array}{c}\mathrm{R}^{2} \\
\text { coefficient of } \\
\text { determination }\end{array}$} & \multirow[b]{2}{*}{ calculated F } & \multirow[b]{2}{*}{ Sig F* } & \multicolumn{5}{|c|}{ Regression coefficient } \\
\hline & & & & & ht & $\beta$ & rror & ed $\mathrm{T}$ & Sig t* \\
\hline The per & 0.359 & 0.129 & 6.354 & 0.034 & Capital Risks & -1.027 & 0.191 & 0205 & 0. \\
\hline Iordanian Islamic banks & & & & & Regression & 1.038 & 0.049 & 23.654 & 0.000 \\
\hline
\end{tabular}

$\left(^{*}\right)$ The effect is statistically significant at $(\alpha \leq 0.05)$.

Source: Author.

The results from Table 5 are that the effect is statistically significant, where calculated $\mathrm{F}$ value is (6.354), and the level of significance ( $\operatorname{Sig} F=0.034$ ) which is less than 0.05 , while the correlation coefficient $(R=0.359)$ refers to the relationship between the variables, in addition to the value of the coefficient of determination was $\left(\mathrm{R}^{2}=\right.$ $0.129)$, pointing out that $(12.9 \%)$ of the variation in (The performance of Jordanian Islamic banks) can be explained by the variation in (Capital Risks) combined, with all other variables constant.

The regression coefficients table showed that the value of $\beta$ when (Capital Risks) has reached (-1.027) and the value of $(\mathrm{t})$ is $(-5.366)$, and the level of significance $(\mathrm{Sig}=0.034)$, suggesting that the effect of this variable is significant.

H01-2: There is no statistically significant impact at the level of significance $(\alpha \leq 0.05)$ for systemic banking risks (Liquidity Risks) on the performance of Jordanian Islamic banks.

Table 6. Examining the effect of systemic banking risks (Liquidity Risks) on the performance of Jordanian Islamic banks

\begin{tabular}{|c|c|c|c|c|c|c|c|c|c|}
\hline \multirow[b]{2}{*}{ Dependent variable } & \multirow{2}{*}{$\begin{array}{c}\mathrm{R} \\
\text { correlation } \\
\text { coefficient }\end{array}$} & \multirow{2}{*}{$\begin{array}{c}\mathrm{R}^{2} \\
\text { coefficient of } \\
\text { determination }\end{array}$} & \multirow[b]{2}{*}{ calculated F } & \multirow[b]{2}{*}{$\operatorname{Sig} F^{*}$} & \multicolumn{5}{|c|}{ Regression coefficient } \\
\hline & & & & & Statement & $\beta$ & Standard error & calculated T & Sig t* \\
\hline The performan & & 04 & & & Liquidity Risks & -0.412 & 0.293 & -2.657 & $\overline{0.311}$ \\
\hline Jordanian Islamic banks & 0.645 & 0.416 & 5.354 & 0.311 & Regression & 1.158 & 0.029 & 19.245 & 0.005 \\
\hline
\end{tabular}

$\left(^{*}\right)$ The effect is statistically significant at $(\alpha \leq 0.05)$.

Source: Author.

The results from Table 6 are that the effect is statistically significant, where calculated $\mathrm{F}$ value is (5.354), and the level of significance ( $\mathrm{Sig} F=0.031$ ) which is less than 0.05 , while the correlation coefficient $(\mathrm{R}=0.645)$ refers to the relationship between the variables, in addition to the value of the coefficient of determination was $(\mathrm{R} 2=$ 0.416), pointing out that $(41.6 \%)$ of the variation in (The performance of Jordanian Islamic banks) can be explained by the variation in (Liquidity Risks) combined, with all other variables constant.

The regression coefficients table showed that the value of $\beta$ when (Liquidity Risks) has reached (-0.412) and the value of $(\mathrm{t})$ is $(-2.657)$, and the level of significance ( $\mathrm{Sig}=0.031)$, suggesting that the effect was significant for this variable. 
H01-3: There is no statistically significant impact at the level of significance $(\alpha \leq 0.05)$ for systemic banking risks (Credit Risks) on the performance of Jordanian Islamic banks.

Table 7. The result of examining the effect of systemic banking risks (Credit Risks) on the performance of Jordanian Islamic banks

\begin{tabular}{|c|c|c|c|c|c|c|c|c|c|}
\hline \multirow[b]{2}{*}{ Dependent variable } & \multirow{2}{*}{$\begin{array}{c}\mathrm{R} \\
\text { correlation } \\
\text { coefficient } \\
\end{array}$} & \multirow{2}{*}{$\begin{array}{c}\mathrm{R}^{2} \\
\text { coefficient of } \\
\text { determination }\end{array}$} & \multirow[b]{2}{*}{ calculated F } & \multirow[b]{2}{*}{$\operatorname{Sig} \mathrm{F}^{*}$} & \multicolumn{5}{|c|}{ Regression coefficient } \\
\hline & & & & & Statement & $\beta$ & Standard error & Calculated T & Sig t* \\
\hline \multirow{2}{*}{$\begin{array}{l}\text { The performance of } \\
\text { Jordanian Islamic banks }\end{array}$} & \multirow{2}{*}{0.386} & \multirow{2}{*}{0.149} & \multirow{2}{*}{4.324} & \multirow{2}{*}{0.117} & Credit Risks & 0.007 & 0.008 & 3.121 & 0.117 \\
\hline & & & & & Regression & 0.817 & 0.037 & 22.232 & 0.000 \\
\hline
\end{tabular}

$(*)$ The effect is statistically significant at $(\alpha \leq 0.05)$.

Source: Author.

The results from Table 7 are that the effect is statistically significant, where calculated $\mathrm{F}$ value is (4.324), and the level of significance ( $\mathrm{Sig} F=0.017$ ) which is less than 0.05 , while the correlation coefficient $(\mathrm{R}=0.386)$ refers to the relationship between the variables, in addition to the value of the coefficient of determination was $\left(\mathrm{R}^{2}=\right.$ 0.149), pointing out that $(14.9 \%)$ of the variation in (The performance of Jordanian Islamic banks) can be explained by the variation in (Credit Risks) combined, with all other variables constant.

The regression coefficients table showed that the value of $\beta$ when (Liquidity Risks) has reached (0.017) and the value of $(\mathrm{t})$ is $(3.121)$, and the level of significance $(\mathrm{Sig}=0.017)$, suggesting that the effect was significant for this variable.

H01-4: There is no statistically significant impact at the level of significance $(\alpha \leq 0.05)$ for systemic banking risks (Operational risks) on the performance of Jordanian Islamic banks.

Table 8. Examining the effect systemic banking risks (Operational risks) on the performance of Jordanian Islamic banks

\begin{tabular}{|c|c|c|c|c|c|c|c|c|c|}
\hline \multirow[b]{2}{*}{ Dependent variable } & \multirow{2}{*}{$\begin{array}{c}\text { R } \\
\text { correlation } \\
\text { coefficient }\end{array}$} & \multirow{2}{*}{$\begin{array}{c}\mathrm{R}^{2} \\
\text { coefficient of } \\
\text { determination }\end{array}$} & \multirow[b]{2}{*}{ calculated $\mathrm{F}$} & \multirow[b]{2}{*}{ Sig F* } & \multicolumn{5}{|c|}{ Regression coefficient } \\
\hline & & & & & Statement & $\beta$ & Standard error & Calculated T & Sig t* \\
\hline \multirow{2}{*}{$\begin{array}{l}\text { The performance of } \\
\text { Jordanian Islamic banks }\end{array}$} & \multirow{2}{*}{0.775} & \multirow{2}{*}{0.601} & \multirow{2}{*}{36.222} & \multirow{2}{*}{0.012} & Operational risks & 0.524 & 0.095 & 5.021 & 0.012 \\
\hline & & & & & Regression & -2.014 & 0.443 & -3.475 & 0.005 \\
\hline
\end{tabular}

$(*)$ The effect is statistically significant at $(\alpha \leq 0.05)$.

Source: Author.

The results from Table 8 are that the effect is statistically significant, where calculated $\mathrm{F}$ value is (36.222), and the level of significance ( $\mathrm{Sig} F=0.012$ ) which is less than 0.05 , while the correlation coefficient $(\mathrm{R}=0.775$ ) refers to the relationship between the variables ,in addition to the value of the coefficient of determination was $\left(\mathrm{R}^{2}=0.601\right)$, pointing out that $(60.1 \%)$ of the variation in (The performance of Jordanian Islamic banks) can be explained by the variation in (Liquidity Risks) combined, with all other variables constant.

The regression coefficients table showed that the value of $\beta$ when (Operational risks) has reached (0.524) and the value of $(\mathrm{t})$ is $(5.021)$, and the level of significance $(\mathrm{Sig}=0.012)$, suggesting that the effect was significant for this variable.

2) H02: There is no statistically significant impact at the level of significance $(\alpha \leq 0.05)$ for systemic banking risks (Capital Risks \& Liquidity Risks \& Credit Risks \& Operational risks) on the performance of Jordanian Islamic banks due to the size of the bank.

In order to examine the second main hypothesis, multiple regression analysis was used, and the results were as follows: 
Table 9. The results of examining the effect of systemic banking risks (Capital Risks \& Liquidity Risks \& Credit Risks \& Operational risks) on the performance of Jordanian Islamic banks due to the size of the bank

\begin{tabular}{|c|c|c|c|c|c|c|c|c|c|}
\hline \multirow[b]{2}{*}{$\begin{array}{c}\text { Dependent } \\
\text { variable }\end{array}$} & \multirow{2}{*}{$\begin{array}{c}\mathrm{R} \\
\text { correlation } \\
\text { coefficient } \\
\end{array}$} & \multirow{2}{*}{$\begin{array}{c}\mathrm{R}^{2} \\
\text { coefficient of } \\
\text { determination }\end{array}$} & \multirow[b]{2}{*}{ calculated F } & \multirow[b]{2}{*}{ Sig F* } & \multicolumn{5}{|c|}{ Regression coefficient } \\
\hline & & & & & Independent variable & $\beta$ & Standard error & calculated $\mathrm{T}$ & Sig t* \\
\hline \multirow{6}{*}{$\begin{array}{l}\text { The performance } \\
\text { of Jordanian } \\
\text { Islamic banks }\end{array}$} & \multirow{6}{*}{0.891} & \multirow{6}{*}{0.794} & \multirow{6}{*}{9.323} & \multirow{6}{*}{0.000} & Capital Risks & -1.745 & 0.621 & -2.858 & 0.032 \\
\hline & & & & & Liquidity Risks & -0.032 & 0.041 & -3.111 & 0.011 \\
\hline & & & & & Credit Risks & 0.014 & 0.016 & 2.944 & 0.033 \\
\hline & & & & & Operational risks & 1.956 & 0.255 & 6.323 & 0.000 \\
\hline & & & & & Size of Bank & -1.972 & 0.333 & -5.122 & 0.000 \\
\hline & & & & & Regression & 16.113 & 5.212 & 3.959 & 0.001 \\
\hline
\end{tabular}

(*) The effect is statistically significant at $(\alpha \leq 0.05)$.

Source: Author.

The results from Table 9 are that the effect is statistically significant, where calculated $\mathrm{F}$ value is (9.323), and the level of significance ( $\operatorname{Sig} F=0.000$ ) which is less than 0.05, while the correlation coefficient $(R=0.891)$ refers to the relationship between the variables, in addition to the value of the coefficient of determination was $\left(\mathrm{R}^{2}=\right.$ 0.794), pointing out that $(79.4 \%)$ of the variation in (The performance of Jordanian Islamic banks) can be explained by the variation in (Capital Risks \& Liquidity Risks \& Credit Risks \& Operational risks \& Size of Bank) combined, with all other variables constant.

The regression coefficients table showed that the value of $\beta$ when (Capital Risks) has reached (1.745) and the value of $(\mathrm{t})$ is $(2.858)$, and the level of significance $(\mathrm{Sig}=0.032)$, suggesting that the effect was significant for this variable. When the value of $\beta$ (Liquidity Risks) amounted to (0.032), and that has a value of (t) is (3.111), and the level of significance ( $\mathrm{Sig}=0.011$ ), suggesting that the effect of this variable is significant. As the value of $\beta$ when (Credit Risks) has reached (0.014) and that has a value of ( $t)$ is (2.944), and the level of significance ( $\mathrm{Sig}=0.033$ ), suggesting that the effect of this variable is significant. As the value of $\beta$ when (Operational risks) has reached (1.956) and that has a value of $(\mathrm{t})$ is $(6.323)$, and the level of significance ( $\mathrm{Sig}=0.000$ ), suggesting that the effect of this variable is significant.

\section{Results}

\subsection{Conclusions}

Having conducted the required statistical analysis and having tested the hypotheses, the following results were revealed:

1). The results of the hypothesis test showed that capital risk had a significant negative effect on return on assets in Jordanian Islamic banks. Also, the increase in these risks leads to a decline in the performance of Islamic banks and thus affects the Bank's ability to meet its obligations, which requires the Bank to maintain adequate capital to face such risks.

2). The results of the hypothesis test showed that operating risk had a significant positive effect on return on assets in Jordanian Islamic banks, where evidence indicates that the Islamic banks are subject to increased exposure to operational risks, including human risk, the risks of automated systems and communications resulting from the increase in banking activity and its ability to manage these risks leads to an increase in the total return on assets. Hence, there was a positive impact of operating risks on the performance of Islamic banks.

$3)$. The results of the hypothesis test showed that there was no impact of liquidity risk on return on assets in Jordanian Islamic banks. This may be due to the liquidity ratios imposed on the banks by the Central Bank. Consequently, there was no significant effect on the performance of Islamic banks.

4). The results of the hypothesis test showed that there is no impact of credit risk on the return on assets in Jordanian Islamic banks. These credit policies in Islamic banks may indicate their risks negligible and therefore require their customers to provide the necessary guarantees if they cannot repay.

5). The results of the hypothesis test showed that combined systemic risk (capital risk, liquidity risk, credit risk, and operational risk) had a significant effect on the performance of Jordanian Islamic banks. This is evident in the study of the effect of operational risks within the systemic risk combined on the return on assets. This may be due to the fact that these risks are the result of real investments and the result of efficient management of the assets. 


\subsection{Recommendations}

Based on the findings of the study, the following recommendations were proposed:

1). The need to develop a department to manage the risks facing the bank by a team that is highly efficient in the management of banking risks.

2). Banks should focus on dealing with formulas with low operational risk and high return on assets.

3). In order to reduce risk, diversification of the Bank's investment and financing operations is necessary to minimize credit risk.

4). The Focus on investments and short-term financing provided to the bank to avoid liquidity risk.

5). The need to pay attention to the human element in the bank through increased training and qualification to reduce the operational risk.

\section{References}

Abdul, K. N. (2007). Operational risks according to the requirements of Basel II A study of the nature and ways of managing them in the case of banks operating in Palestine. Published Paper, Fifth Annual Scientific Conference, Philadelphia University, Jordan, 4-5/7/2007, Amman, Jordan, p. 10.

Abdulhameed, A. (2000). Comprehensive Banks Operations and Management (p. 231). Dar Aljameia, Egypt.

Abu Al-Hija, M. A. (2004). Effect of Volume Difference on Return on Assets in Jordanian Public Shareholding Companies (1990-2001). Unpublished Master Thesis, Al-Bayt University, Mafraq, Jordan, p. 23.

Ajlouni, M. (2008). Islamic banks, their provisions, principles and banking applications (1st ed., p. 416). Amman, Jordan: Dar Al Masirah for Publishing and Distribution.

Akashi, A. B. (2013). The impact of operational risks on the profitability of Islamic banks operating in Jordan. Unpublished PHD Dissertation, the World Islamic Sciences \&Education University, Amman, Jordan.

Al-Hamdan, N., \& Iqda, A. (2013). Effect of capital structure on the performance of Jordanian banks listed on the Amman Stock Exchange: An analytical study. Al-Manar Journal, 19(4), 174.

Al-Henawi, M. S., \& Abd al-Salam, S. A. (2000). Financial Institutions - Stock Exchange and Commercial Banks (p. 274). Dar Aljameia, Egypt.

Al-Rayhan, B. (2002). The relationship of Islamic banks with central banks (p. 41). Publications of the Jordanian Islamic Bank, Jordan.

Alwefaq, A. (2003). Operational Risks. Journal of Financial and Banking Studies, 10(4), 30.

Beltagy, M. (2005). Proposed Model for Measuring Islamic Banking Risks. Symposium on Islamic Banking Risk Measurement, Saudi Arabian Monetary Agency, Saudi Arabia. Retrieved JAN 9, 2014 from http://www.bltagi.com/ar/?p=154/

Boukri, A. A. R. (2005). The risks of Islamic commercial financing formulas in Saudi banks. Unpublished PHD Dissertation, Umm Al Qura University, Makkah, Saudi Arabia.

Haddad, F. S. (2012). The relationship between economic value added and stock returns: Evedence from Jordanian Banks. EURO journals publishing Ine.

Hammad, H. A. K. (2008). The risks of investing in Islamic banks are their concept, their nature, their sources, and their effects. Published Master Thesis, Amman, Jordan.

Hammad, T. A. (1999). Evaluation of Commercial Banks Performance - Risks and Return Analysis (pp. 73-74). Dar Aljameia, Egypt. Retrieved JAN 9, 2014 from http//www. Cbj. gov/Arabic

Hammad, T. A. (2003). Risks Management (p. 239). Dar Aljameia, Alexandria, Egypt.

Issa, M. H. (2010). Risks Management of Credit Portfolios (1st ed., p. 70). Dar Al Raya, Amman, Jordan.

Khan, T. A. (2001). Risks Management Analysis of Islamic financial industry issues. Research published in Islamic Institute for Research and Training Islamic Development Bank, Edition1, Jeddah, Saudi Arabia.

Khan, T. A. (2003). Risks Management Analysis of Issues in the Islamic Finance Industry (p. 31). Islamic Development Bank, Jeddah.

Koch, \& Scott. (2006). Bank Management, Analysing Bank Performance (6th ed., pp. 225-320). MG Hill.

Matar, M. (2003). Recent Trends in Credit Analysis Methods, tools and general uses (p. 28). Amman, Jordan: 
Dar Wael Publishing.

Matar, M., \& Tim, F. (2005). Investment Portfolio Management (p. 43). Amman, Jordan: Dar Wael Publishing \& Distribution.

Mohammad, A. (2013). The extent to which financial analysis is consistent with the information content of the cash flow statement is an analytical study based on the data of a number of international companies. Journal of Baghdad College of Economic Sciences, (34), 346.

Ramadan, Z. S., \& Juda, M. A. (1996). Management of Banks (p. 285). Amman, Jordan: Dar Safa Publishing and Distribution.

Shammary, S. R. (2014). Management of Banking Operations (Introduction and Applications). Edition 4, Dar Al Yazuri.

Shehzad, M. M. (2008). Performance of Islamic Banking and Conventional Banking in Pakistan: A Comparative Study. Master Degree Project in Finance Advance Level 1/15p ECTS Spring Term 2008, School of Technology and Society.

Tahrawi, A., \& Ben Habib, A. R. (2013). Risks Management in Islamic Banking under Basel Standards. Islamic Economic Studies (IRT), 19(1).

The Financial Service Roundtable (FSR). (1999). Guiding Principles in Risk Management for US Commercial Banks (p. 5). Retrieved JAN 9, 2014 from https://books.google.comGuiding_Principles in Risk

The Institute of Internal Auditor (IIA) USA. Retrieved JAN 9, 2014 from https://www.theiia.org

Zurqan, S. T. (2010). Financial Analysis and its Impact on Credit Risks: An applied study on a sample of Jordanian commercial banks. Journal of Baghdad College of Economic Sciences, (23), 278.

\section{Copyrights}

Copyright for this article is retained by the author(s), with first publication rights granted to the journal.

This is an open-access article distributed under the terms and conditions of the Creative Commons Attribution license (http://creativecommons.org/licenses/by/4.0/). 